\title{
Bos primigenius Bojanus, 1827 from the Early Late Pleistocene Deposit of Avetrana (Southern Italy) and the Variation in Size of the Species in Southern Europe: Preliminary Report
}

\author{
Luca Pandolfi, Carmelo Petronio, and Leonardo Salari \\ Department of Earth Science, Sapienza University of Rome, Piazzale Aldo Moro 15, 00185 Rome, Italy \\ Correspondence should be addressed to Carmelo Petronio, carmelo.petronio@uniroma1.it
}

Received 29 December 2010; Accepted 18 April 2011

Academic Editor: Josep Pares

Copyright ( 2011 Luca Pandolfi et al. This is an open access article distributed under the Creative Commons Attribution License, which permits unrestricted use, distribution, and reproduction in any medium, provided the original work is properly cited.

\begin{abstract}
Very abundant remains of Bos primigenius have been recovered in the early Late Pleistocene site of Avetrana (southern Italy). The site is characterized by a karst filling originated from a series of almost coeval depositional events. This discovery represents a rare record in the early Late Pleistocene of southern Europe. Biometrical analysis of the metapodial bones of aurochs from Avetrana gave the cue to examine the evolutive trend of the species in southern Europe, from the Middle Pleistocene to Holocene. This trend is characterized by an increase in size of the metapodial bones from Middle Pleistocene to early Late Pleistocene and to a decrease in size of the same during the late Late Pleistocene and Holocene. Also, the variations in size are competed by change in shape of the metapodial bones. These variations seem to be related with climatic fluctuations and competitions with Homo and Bison. At least, five evolutive stages are recognized; they constitute an important tool for the biochronological correlations among the Pleistocene sites of southern Europe.
\end{abstract}

\section{Introduction}

The auroch, Bos primigenius Bojanus 1827, object of the present paper, was found in a karst cavity in an abandoned quarry near Avetrana (Figure 1), a small town in the south-eastern area of Taranto, in the northern part of the Salento peninsula (Apulia, southern Italy) [1, 2]. The karst filling is rich in bone remains, notably of mammals, which originated during the Pleistocene within rocks, attributed to the Early Pleistocene formation of the so-called "Calcareniti di Gravina." The cavity is filled with this material which was carried by alluvial flows, very likely the consequence of several exceptional events (which were distinct but chronologically coeval, from a geological point of view).

The "Calcarenite di Gravina," attributed to the Early Pleis-tocene, sensu Gibbard et al. [3], is at least 15 meter thick and composed by a compact yellowish biocalcarenite, rich in molluscs and echinoids. It was deposited in a coastal marine environment, with a temperate climate and shallow waters [4].

A preliminary analysis of the avifauna, and chiefly the biochronology of the mammal-fauna found in the cavity, allowed us to assign a quite large chronological span to the deposition of sediments, although pertaining to the Late Pleistocene [1]. Later, Petronio et al. [2], on the base of the faunal assemblage, refer the deposit to the early Late Pleistocene (Melpignano Faunal Unit in the Italian biochronology, sensu Petronio et al. [5]) (Figure 2).

The new discovery of auroch remains mostly from Layer 5 of the Avetrana site, particularly well-preserved metapodial bones, is on the base of this paper. In southern Europe, the remains of auroch referable to the early Late Pleistocene seem to be very scarce, so, the data from Avetrana are an important contribution to the knowledge of this species during the considered time span.

The analysis of biometrical characters of the metacarpal and metatarsal bones from Avetrana gave the cue to examine 


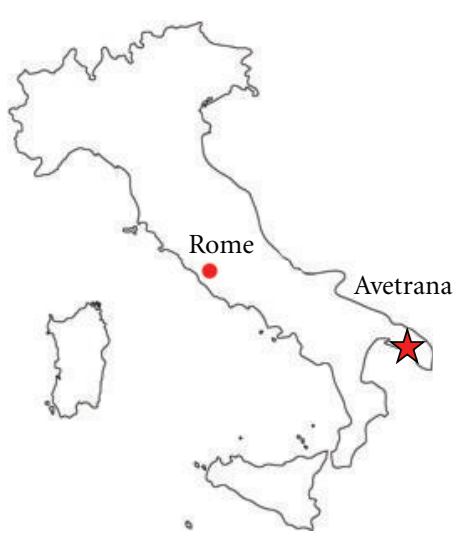

(a)

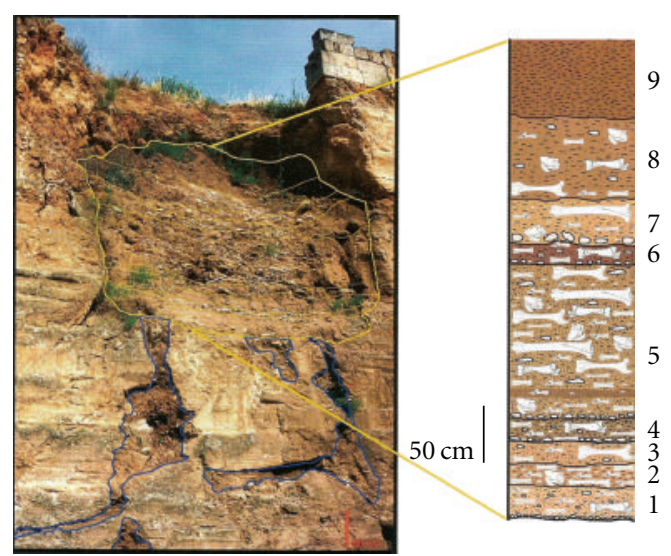

(b)

FIGURE 1: Location of the site of Avetrana (a) and stratigraphy of the fossiliferous deposit (b). 1-9 are the different layers.

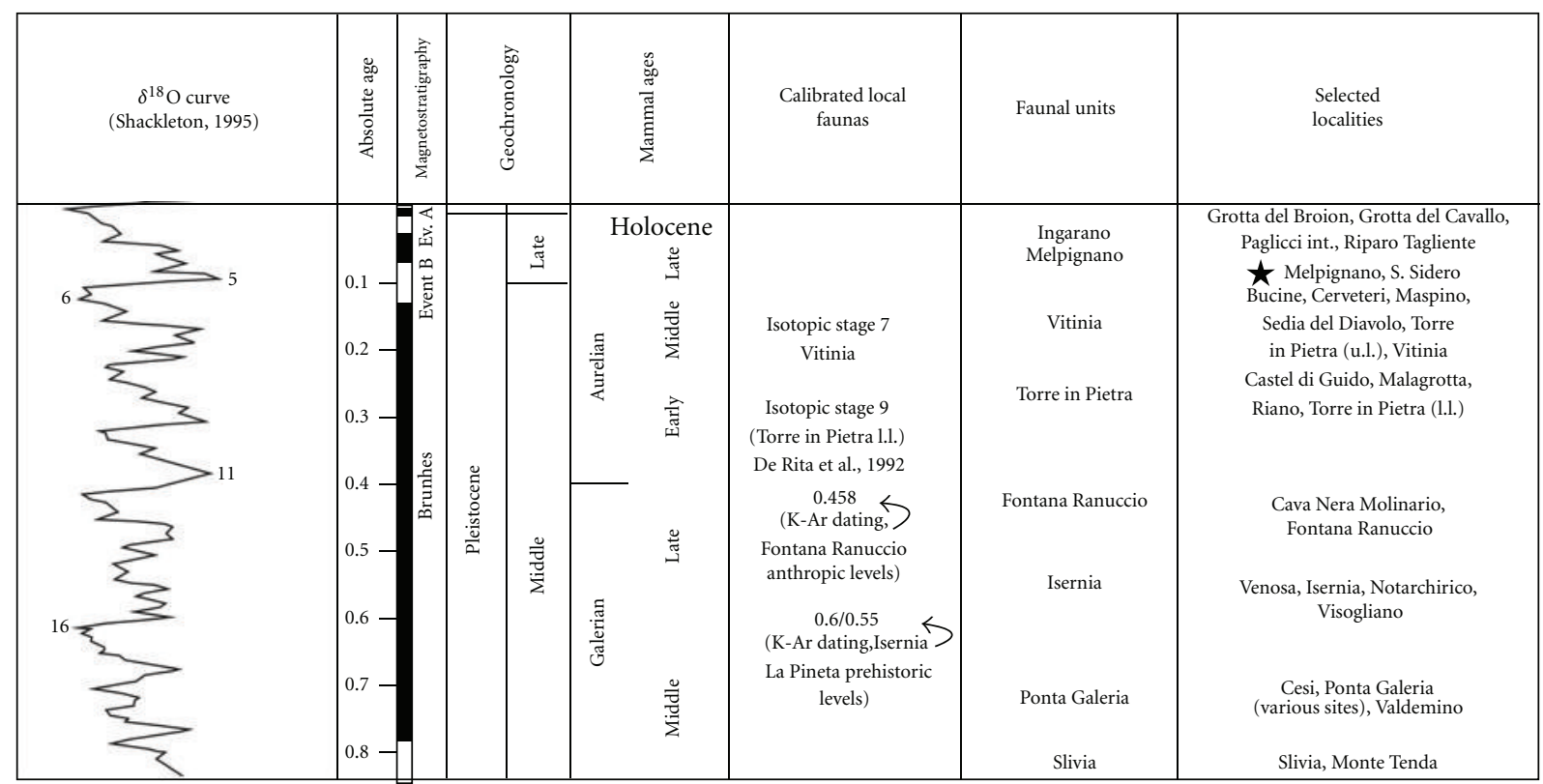

Figure 2: Italian mammal biochronology of the Middle and Late Pleistocene according to Gliozzi et al. [6] and Petronio et al. [7]. The red star indicates the biochronological position of the site of Avetrana.

the evolutive trend of the species in southern Europe, from the Middle Pleistocene to Holocene.

The results of this analysis aim to relate the body sized variations of the auroch with climatic fluctuations or species competitions. These variations, and the possible correlations with particular events, may facilitate the biochronological correlations between the Middle and Late Pleistocene sites of southern Europe and their paleoenvironmental interpretations.

\section{The Site of Avetrana, Stratigraphy, and Biochronology}

Petronio et al. [2] recognized 9 layers and 2 pockets (Figure 1) in the filling of the karst fissure where the bone remains were discovered. These sediments may be divided into two groups: the upper one fills the main karst cavity and includes 9 levels, while the lower one forms the layer 0 which fills a network of small basal fissures. Layer 0 is filled with orange-yellow nonlaminated sandy clays containing small and medium sized fossil vertebrate remains. On the other hand, the main cavity is filled with a series of laminated sediments and it is between 4.5 to 5.5 meters thick. It is possible to draw up a list of the most important features of the different layers identified, on the base of the stratigraphic elements observed in the cavity and also on the base of the systematic study carried out on the paleontological contents of the deposits.

Regarding the genesis of the deposit, the observations made on the structure of the cavity, on the sediments of 
the filling, the physical status, and spatial disposition of the fossil bones suggest that the stratification originated from a series of depositional events, which were independent, exceptional, and almost coeval. The fossil bones are usually well preserved, with the exception of those of Layer 9. No clear evidences of human activity and of gnawing by rodents and carnivores have been checked, several bones are fractured. Different parts of the skeleton of the ungulates are not equally distributed. These data suggest the main role of sin- and postdepositional physical and chemical factors. Water has been the main, if not the only one, depositional factor. Moreover, many bones are complete, some of them articulated, without clear signs of transport. Thus, carcasses (in particular those of $B$. primigenius) were not carried by water for long distances, their disposition being quite chaotic in the deposit. Some intentional fractures and some probable cutmark can be noticed only on a hippo humerus and a few phalanges of auroch. These, together with the collection of a single Mousterian tool, suggest a human frequentation of the area, but without an active role in the deposit formation. The lower part of the karst cavity, including the little fissures of Layer 0, was only filled by debris and by small bones, because it was the only material which could pass through the small karst microfissures. The actual levels of the main cavity (Layers 1-9), underwent a slight modification and remixing on the top. Moreover, due to the lack of evident surfaces of erosion and of palaeosoils, we cannot determine any periods of outcrop and exposure. The run-off water and the floodwater, probably due to conspicuous showers or to the overflow of adjacent streams, caused the detrital sediments, the clasts of various dimensions, and the bones of the vertebrates which the water found along its way, to be carried inside the karst fissure.

The faunal assemblage including Perdix perdix, Otistarda, Columba livia, Athene noctua, Pyrrhocorax graculus, and $P$. pyrrhocorax, among birds, Erinaceus europaeus, Terricola savi, Hystrix vinogradovi, Lepus cf. europaeus, Oryctolagus cuniculus, Canis lupus, Vulpes vulpes, Meles meles, Crocuta crocuta, Lynx lynx, Felis silvestris, Panthera leo, Stephanorhinus hemitoechus, Hippopotamus amphibius, Sus scrofa, Dama dama dama, Cervus elaphus elaphus, and Bos primigenius, among mammals [2]. The presence of $H$. vinogradovi in the faunal assemblage represents a first significant element for the biochronological collocation, due to the fact that this rodent becomes extremely rare during the Late Pleistocene $[8,9]$. In fact, there is some evidence of porcupines in the Late Pleistocene, but they are the remains of a discussed stratigraphic position $[8,10]$. Therefore, the remains of $H$. vinogradovi found among the faunal remains in the site of Avetrana are, at the present time, the most recent discovery in Italy and one of the southernmost of Europe [9]. Also the report of the remains of hippopotamus becomes even rarer during the Late Pleistocene, limiting the late chronological interval that we must consider for the faunal assemblage of Avetrana. In fact, among the remains of the entrance to the cave of Ingarano (northern Apulia, southern Italy), along with the remains of Coelodonta antiquitatis, the last appearance of H. amphibius in Italy is cited [11]. The latter, according to our knowledge today of the first manifestation of the woolly rhino in Italy, allows us to link the fossiliferous sediments of Ingarano with Marine Isotopic Stage $4[5,11]$. The dental structures of the remains of $D$. dama dama represent a morphological element which limits the inferior chronological interval of the faunal assemblage from Avetrana. This element indicates a temporal interval which is posterior to the late Middle Pleistocene. The molarized premolars, and the cingula which are clearly evident allow us to lean toward the first archaic forms of the modern fallow deer [12]. Also the modernness of the antlers of $C$. elaphus causes us to exclude elaphine forms from the Middle Pleistocene [13]. However, also the presence as well of a quite archaic Mousterian artifact [2] is not in contrast with this faunal assemblage, even if it is not sufficient to define a precise chronological interval.

The hypothesis that the fossiliferous deposit was the result of a series of individual events, which occurred close to each other, is corroborated and confirmed by the presence of this faunal assemblage which is coherent from a chronological point of view. The assemblage remains practically unaltered in its general features, aside from the different levels. This is possible only when the time passed from the first and the last event is geologically insignificant. Some general considerations on the paleoenvironmental conditions of the area derive in particular from the presence at Layer 0 of Terricola savii, and of the lagomorphs, which indicate the presence of a temperate environment characterized by large ample spaces. This aspect is also confirmed by the avifauna. In fact, the fossil remains of birds found in Avetrana, even if belonging to a few species, provide us with homogeneous indications from an ecological point of view, allowing us to retrace the Avetrana habitat during the phases of the formation of the fossiliferous deposit. All the species found are linked to an open environment with the presence of rocky outcrops on which it is possible to nidificate. This is mostly suggested by the discovery in the deposit of Athene noctua, Columba livia, Pyrrhocorax graculus, and $P$. pyrrhocorax. The open areas were inhabited by other species (i.e., Otis tarda and Perdix perdix).

Regarding the faunal assemblage of the large mammals, we can gather general information concerning an environment characterized by an open forest, or by a grasslandpark, variously wooded. The great quantity of aurochs and the presence of red deer and fallow deer emphasize an environment characterized by large wooded areas, that are rich in glades, with both ample and open spaces where, presumably, the rhinoceros and the most part of the carnivorous forms (found in the faunal assemblage) lived. The wild pig and hippopotamus were also present, even though they were not copious, suggesting the presence of expanses of water and of an area which was more humid than the actual one.

\section{Materials and Methods}

The fossil material of Avetrana was measured according to the methodologies suggested by von den Driech [14], and it was compared with the corresponding anatomical parts of fossil aurochs from a more that twenty localities of Italy and central and southern Europe, referable to the Middle Pleistocene, Late Pleistocene, and Early Holocene: among 
TABle 1: Osteometric measurements, in mm, of metacarpus and metatarsus of Bos primigenius from Avetrana (southern Italy). MC: Metacarpus; MT: Metatarsus; Lmax: greatest length; PTD: Proximal Transverse Diameter; PAPD: Proximal Antero-Posterior Diameter; MTD: Transverse Diameter of the Shaft; MAPD: Antero-Posterior Diameter of the Shaft; DTD: Distal Transverse Diameter; DAPD: Distal Antero-Posterior Diameter; F: Female; M: Male; ?: not known sex.

\begin{tabular}{|c|c|c|c|c|c|c|c|c|c|}
\hline & Specimen & $\mathrm{L} \max$ & DPT & DPAP & DMT & DMAP & DDT & DDAP & Sex \\
\hline \multirow{20}{*}{ MC } & ANS 1 & 264.00 & 80.50 & 49.40 & 47.60 & 32.60 & 84.70 & 44.20 & $\mathrm{~F}$ \\
\hline & ANS2 & 268.00 & 79.20 & 47.90 & 48.50 & 33.70 & 81.50 & 44.40 & $\mathrm{~F}$ \\
\hline & ANS3 & 275.00 & 84.10 & 50.00 & 50.50 & 34.70 & 84.20 & 43.20 & $\mathrm{~F}$ \\
\hline & ANS4 & 251.00 & - & - & 47.50 & 33.60 & 79.80 & 41.90 & $\mathrm{~F}$ \\
\hline & ANS5 & 271.00 & 74.00 & 45.20 & 43.50 & 31.10 & 80.10 & - & $\mathrm{F}$ \\
\hline & ANS7 & 265.00 & 80.60 & 47.50 & 49.30 & 34.30 & - & - & $\mathrm{F}$ \\
\hline & ANS8 & 268.00 & 79.50 & 47.90 & 48.60 & 34.80 & - & - & $\mathrm{F}$ \\
\hline & ANS9 & 259.00 & 77.20 & 47.90 & 45.90 & 32.20 & - & - & $\mathrm{F}$ \\
\hline & ANS10 & 252.00 & 65.00 & 43.70 & 36.70 & 32.20 & - & - & $\mathrm{F}$ \\
\hline & A6 8 & 253.00 & 83.00 & 50.60 & 45.80 & 31.40 & 79.10 & 42.00 & $\mathrm{~F}$ \\
\hline & A6 19 & - & - & - & - & - & 74.60 & 36.30 & $?$ \\
\hline & A5 22 & 275.00 & 77.00 & 48.00 & 46.30 & 30.40 & 79.30 & 39.70 & $\mathrm{~F}$ \\
\hline & A5 31 & - & 71.20 & 43.00 & 43.10 & 31.20 & - & - & $?$ \\
\hline & A2 B 22 & - & 77.70 & 45.10 & 44.00 & - & - & - & $?$ \\
\hline & A6 78 & - & - & - & - & - & 95.40 & - & M? \\
\hline & A6 79 & - & - & - & - & - & 91.10 & 48.10 & M? \\
\hline & A6 80 & - & - & - & - & - & 83.40 & 43.10 & $?$ \\
\hline & A6 81 & - & - & - & - & - & 80.30 & 43.10 & $?$ \\
\hline & A6 82 & - & - & 44.50 & 40.20 & 31.10 & - & - & $?$ \\
\hline & A7 B 03 & - & 69.30 & 42.50 & 39.00 & 29.60 & - & - & $?$ \\
\hline \multirow{20}{*}{ MT } & ANS6 & 302.00 & 64.40 & 64.30 & 40.10 & 43.50 & 73.20 & 44.90 & $\mathrm{~F}$ \\
\hline & ANS11 & 288.00 & 61.50 & 60.20 & 41.10 & 42.20 & 71.20 & 38.90 & $\mathrm{~F}$ \\
\hline & A6 9 & - & 55.40 & 54.40 & - & - & - & - & $?$ \\
\hline & A6 69 & - & 56.70 & 58.60 & 32.20 & - & - & - & $?$ \\
\hline & A6 70 & - & 64.80 & 64.30 & - & - & - & - & $?$ \\
\hline & A6 71 & - & 65.30 & 66.10 & - & - & - & - & $?$ \\
\hline & A6 72 & - & - & - & 38.00 & - & - & - & $?$ \\
\hline & A6 73 & 302.00 & 66.80 & 65.30 & 37.60 & 36.30 & 73.30 & 40.40 & $\mathrm{~F}$ \\
\hline & A6 74 & - & 66.70 & 65.10 & 44.60 & - & - & - & $?$ \\
\hline & A6 75 & - & 65.20 & 64.00 & 40.00 & - & - & - & $?$ \\
\hline & A6 76 & - & - & - & - & - & 72.80 & 38.70 & $?$ \\
\hline & A6 77 & - & - & - & - & - & - & 39.80 & $?$ \\
\hline & A5 23 & 295.00 & 61.00 & - & 45.00 & 36.70 & 74.50 & 37.80 & $\mathrm{M}$ \\
\hline & A5 35 & - & - & - & - & - & 71.40 & 37.90 & $?$ \\
\hline & A5 103 & - & 53.40 & 53.60 & 34.60 & 35.00 & - & - & $?$ \\
\hline & A5 104 & - & 50.00 & 60.40 & 30.30 & - & - & - & $?$ \\
\hline & A8 B 4 & - & - & - & - & - & 75.80 & 43.00 & $?$ \\
\hline & A2 B 1 & - & 57.30 & 61.50 & 35.20 & 37.10 & - & - & $?$ \\
\hline & A7 B 4 & - & 67.80 & 66.90 & 40.00 & - & - & - & $?$ \\
\hline & Bos p. NC & 295.00 & 60.80 & 60.00 & 38.80 & - & 73.10 & 38.60 & $\mathrm{~F}$ \\
\hline
\end{tabular}

the other, Venosa (IT), GRA Km 2 of Rome (IT), Via Aurelia near Rome (IT), Malagrotta (IT), Grotte di Santo Stefano (IT), Cava Fiora (IT), Passo Corese (IT), Melpignano (IT), Barche di Solferino (IT), Las Grajas (E), Lunel-Viel (FR), Tourville-la-Rivière (FR), Fontéchevade (FR), La Calmette (FR), La Rouquette (FR), Epinette (FR), Achenheim (FR), Holstein $(\mathrm{CH})$, Stranska-Skala (former CZ), Nagybajom, and other sites of Hungary and various localities of Denmark. The osteometric measurements of metacarpus and metatarsus (Table 1) considered to estimate the evolutive trend of B. primigenius have been directly taken by authors (in particular for the Middle and Late Pleistocene sites of Italy) and in part from the literature [15-35]. As regards the age of the considered sites, we have chosen to resort 


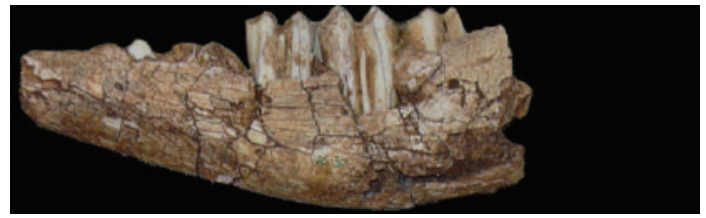

(a)

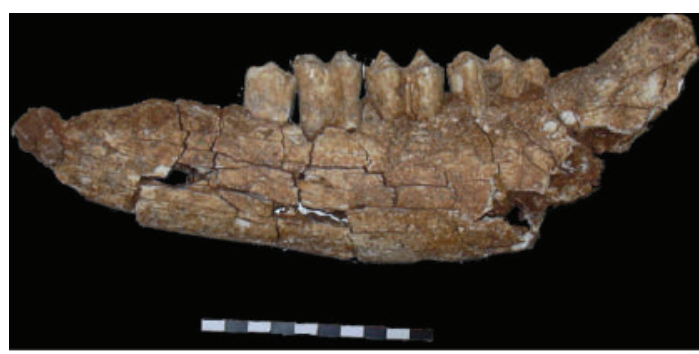

(b)

FIGURE 3: Hemimandibles of auroch from Avetrana (southern Italy). (a) left hemimandible; (b) left hemimandible. Scale bar: $10 \mathrm{~cm}$.

to the Geological Time Scale recently reported by Gibbard et al. [3]. In particular the data have been divided into three great groups referable to Middle and Late Pleistocene and to Holocene. Also, for a detailed analysis we have distinguished the Middle Pleistocene into three chronological time spane: MPL0 = Middle Pleistocene, about 650-500 ka, chronologically referred to the Isernia FU sensu Petronio and Sardella [36]; MPL1 = late Middle Pleistocene, about 480$300 \mathrm{ka}$, chronologically referred to the Torre in Pietra FU sensu Gliozzi et al. [6]; MPL2 = latest Middle Pleistocene, about 300-200 ka chronologically referred to the Vitinia FU, according to Gliozzi et al. [6], supplemented by Petronio et al. [7] (Figure 2). The Late Pleistocene have been divided into two-time span: LPL1 = early Late Pleistocene, about 125-80 ka and LPL2 = late Late Pleistocene, about 75-20 ka.

With the data of the metapodial bones for the different considered sites, box plots have been built; with these last, the relative variations in the time of the biometrical characters of the same skeletal element are analyzed. Also, diagrams of the ratio between the measurements of the diaphysis versus the two epiphysis built. The results have been divided with the means of the same of Bison priscus from Cava Filo (data from Sala [37]); this is to better show the variations in shape of the metapodial bones during the time. Simpson diagrams have been built for the metacarpus and metatarsus, using as reference Bison priscus from Cava Filo (data from Sala [37]).

In all the biometrical analysis, we have chosen to consider only the female individuals; this choice is based on the facts that the sexual dimorphism of the species is very marked (see among [18, 33, 38]) and in Avetrana the complete metapodial bones of auroch are represent only by female (excluding a single metatarsus that was not considered in the analysis).

The sex of the auroch was estimated on the base of Principal Component Analysis (PCA), of the dimensional characters of the metapodial bones and using the coefficients of Howard [39] for the domestic cattle. As regards PCA analysis, the original variables were transformed into new variables that have zero intercorrelation. Principal components were extracted from the correlation matrix of osteometric data. These last are represent by the ratio between the transverse diameter of the proximal and distal epiphysis and of the diaphysis versus the greatest length.

The estimate age of death was calculated considering the age of fusion of epiphysis of the long bones, the teeth eruptions, change, and attrition, considering the tables reported in Silver [40] and Barone [41] for present domestic cattle. The minimum number of individuals, for each level, was calculated considering the side of each bones (right or left) and the more frequent skeletal element (molars and metacarpal bones) of only one side. The result was integrated with the analysis of the dimensional characters, sex, and age of the other skeletal elements.

The estimate of the withers height was carried out by multiplying the length of the tibia, metacarpus, and metatarsus by the coefficients of Matolcsi [42] for present domestic cattle.

\section{Bos primigenius Bojanus, 1827 from Avetrana}

This bovid is the best represented species in the site of Avetrana. Its bones are all of large dimension and were found at all the stratigraphic layers, where they represent the most frequent and numerous specimens.

The largest part of the remains is composed of long bones, vertebrae, ribs, phalanges, and teeth. Except for a limited number of elements, which are referable to young subjects, almost the whole of the bones is attributable to adult and subadult specimens, in which the epiphyses are already completely knitted.

As for the cranial elements, a lot of fragmented maxillaries, some cranial bones and one intact frontal bone with horns were discovered. The hemimandibles (Figure 3) were very rarely found, often they are fragmented and frequently only constituted by the alveolar portions of the teeth. The upper and lower teeth are the most recurrent remains. On the whole they are in very good condition and mostly belong to adult individuals. The horn-core morphology and some morphological and morphometrical characters (the upper molars with columnar and hypsodont appearance, the third lower molar with large and high ectostylid, and the distal end of the metapodial bones with the natural prolongation of the line of the diaphysis) excluded the presence of other bovine species, as Bison priscus or Bubalus murrensis (see $[33,37,43])$.

The best preserved and intact bones are represented by complete skeletal elements, as one tibia, some radii, numerous metacarpi, several metatarsi, many carpal and tarsal bones and very copious first, second, and third 


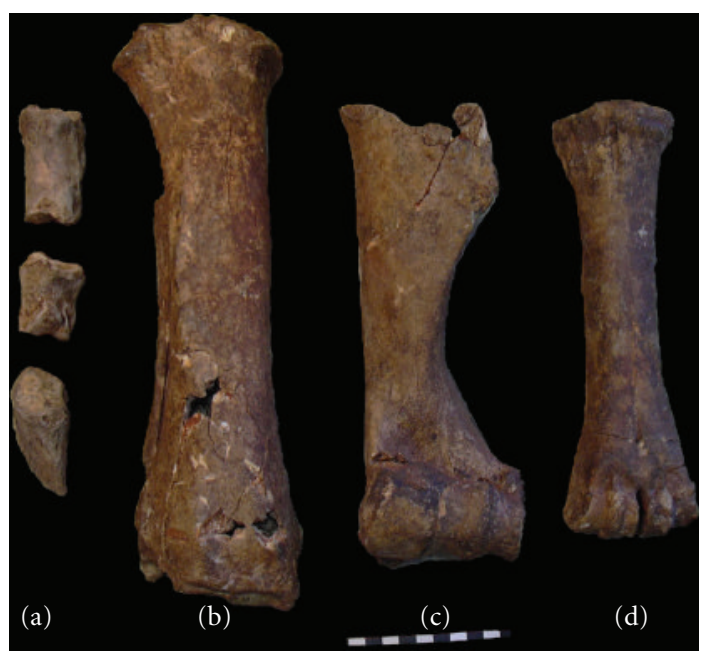

Figure 4: Postcranial remains of auroch from Avetrana (southern Italy). (a) from top to down, proximal, medial, and distal phalanges; (b) right radius, dorsal view; (c) left humerus, anterior view; (d) right metacarpus, dorsal view. Scale bar: $10 \mathrm{~cm}$.

phalanges (numerous are still in anatomical connection) (Figures 4 and 5).

The tooth and bone remains are in total referred to at least 37 individuals: a young calf of few months (a very small metatarsus with proximal epiphysis just merged), three calves of less than two years old (metapodial bones with distal epiphysis not-join), four young individuals of just over two years (not-wear third lower molars), one individual of about 28-34 month (mandible with fourth premolar in eruption), and at least 28 adult individuals with upper and lower teeth (particularly the third lower molar was considered) in different stage of attrition. Even if we cannot exclude that the biology of B. primigenius and their absolute ages were slightly different from the present-day domestic cattle, however the estimated relative ages are probably similar.

Both the principal component analysis (PCA) of the metapodial bones and the Howard coefficients [40] show that the aurochs of Avetrana are predominantly females. Solely one intact metatarsus and a few distal portions of metacarpus are included in the range of size variability of the B. primigenius male.

The estimated withers height shows a population of auroch with a mean height of about $159.1 \mathrm{~cm}$ (between 159.1 and 163.4 from radius, $153.5 \mathrm{~cm}$ from tibia, between 151.4 and $165.8 \mathrm{~cm}$ from metacarpus and between 153.5 and $165.8 \mathrm{~cm}$ from metatarsus) and $158.8 \mathrm{~cm}$ considering the female only.

\section{Biometrical Analysis of Metapodial Bones}

The population of the auroch from Avetrana seems to be biometrically homogeneous and it is constituted mainly by adult females (Figure 6). So, to compare the data of the metapodial bones from Avetrana with the other from the different European sites, we have excluded the males. This

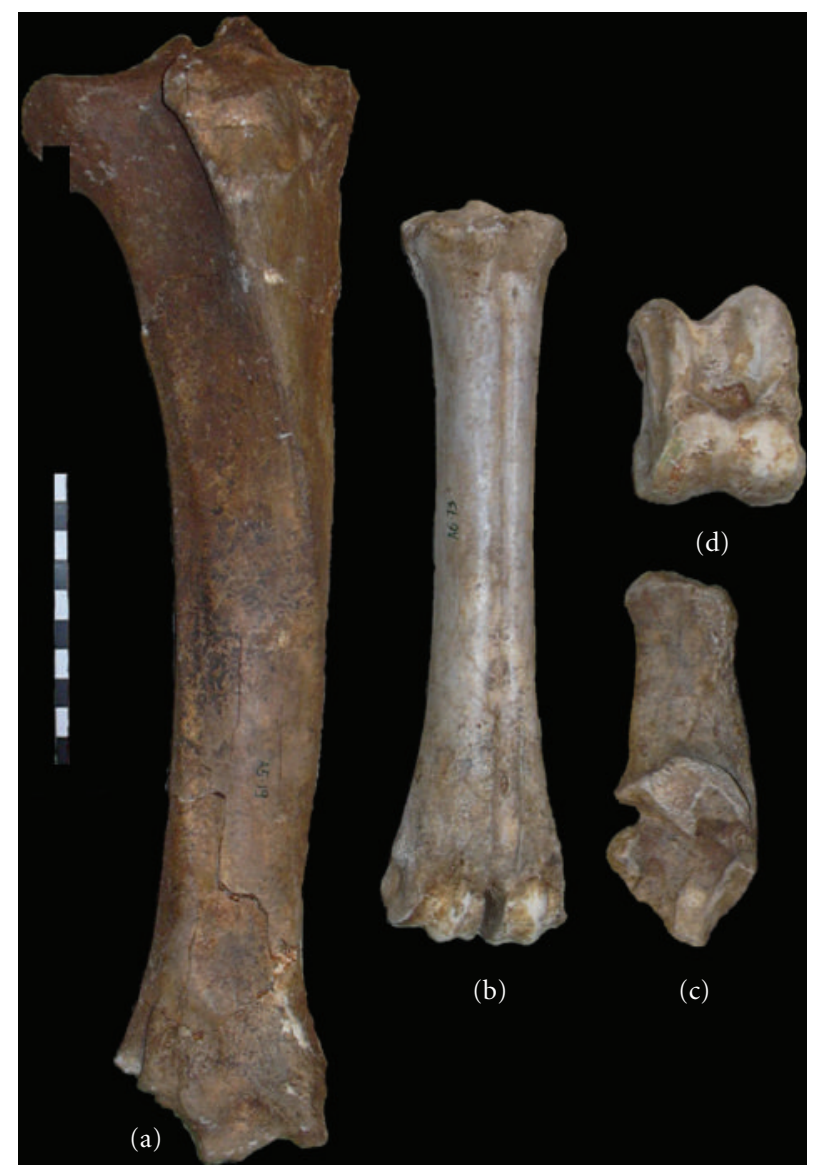

Figure 5: Postcranial remains of auroch from Avetrana (southern Italy). (a): right tibia, anterior view; (b): left metatarsal, dorsal view; (c): right calcaneum, medial view; (d): left talus, dorsal view. Scale bar: $10 \mathrm{~cm}$.

fact is due to the sexual dimorphism of the species that can alter the results of the diagrams.

The box plot (Figure 7) relative to the greatest length of the metacarpus show the dimensional trends of the different populations in the considered time spans. From left to right are reported the six chronological intervals from the first occurrence of the species (Middle Pleistocene) (MPL0) to Holocene. As shown in the box plot, the greatest length of the metacarpus has a general increase during the late Middle Pleistocene (MPL1 and MPL2), with a maximum in correspondence to the early Late Pleistocene (represent by the sites of Avetrana and Melpignano). An opposite trend is recognized from the late Late Pleistocene (LPL2) to Holocene.

The same tendency is recognized even for the distal transverse diameter of the metacarpus (Figure 8). As for the greatest length, the maximum point is recorded in correspondence to the early Late Pleistocene (only Avetrana). Unfortunately, the data about the late Late Pleistocene are very scarce and are not represent in the box plot.

What has been shown for the metacarpus, it is visible for the metatarsus in the box plot concerning the greatest length (Figure 9), although the data of female about this bone 


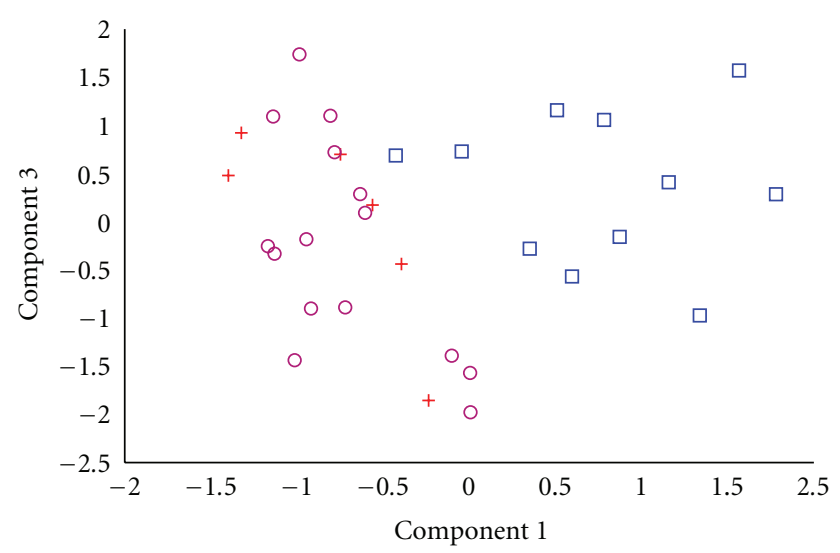

Figure 6: Bivariate diagram of the scores on the first and third principal components of the metacarpus of Bos primigenius from Avetrana (red cross) and males (square) and females (circle) from different Pleistocene sites of southern Europe (data from 17, 21, 23, 30) (component scores standardized to a zero, standard deviation $=$ $1)$.

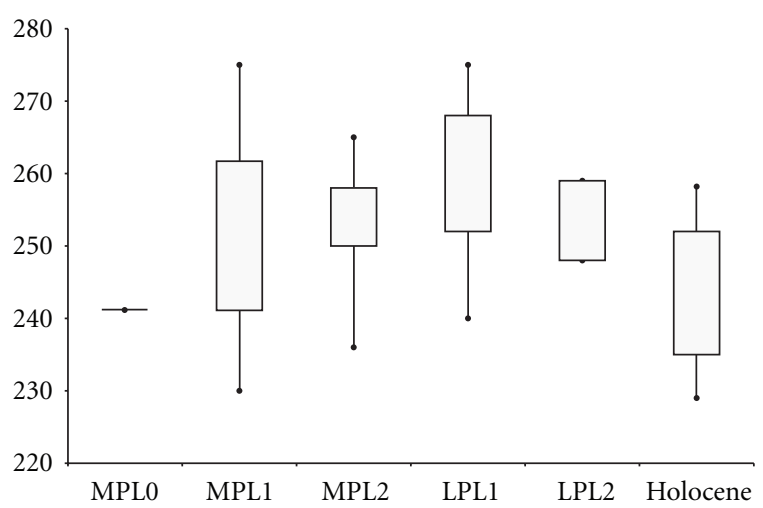

Figure 7: Box plot for the greatest length of the female metacarpus of Bos primigenius from Avetrana and from different sites of southern Europe (data from 13, 14, 15, 16, 17, 18, 19, 20, 21, 22, 23, 24, 25, 26, 27, 28, 29, 30, 31, 32, 33). MPL0: Middle Pleistocene, about 650-500 ka; MPL1: late Middle Pleistocene, about 480-300 ka; MPL2: latest Middle Pleistocene, about 300200 ka; LPL1: early Late Pleistocene, about 125-0,80 ka; LPL2: late Late Pleistocene, about 75-20 ka.

are more scarce. The same dimensional variations during the time observed in the metacarpus is also recognized in the metatarsus, with the least values during the Middle Pleistocene (MPL0) and Holocene and the great values during the late Middle Pleistocene (MPL2) and early Late Pleistocene (represent by the site of Avetrana).

Furthermore, a general change in the shape of the metapodial bones is observable in the diagram concerning the ratio between the transverse diameter of the diaphysis versus the epiphysis of the same bone (Figure 10). In particular, during its first occurrence (MPL0), the species is characterized by a "clepsydra" shape of the metatarsus. In this bone, the two epiphysis, and in particular the distal epiphysis, seem to be more developed than the diaphysis; thus, the metatarsus seems to be more slender. The same shape of

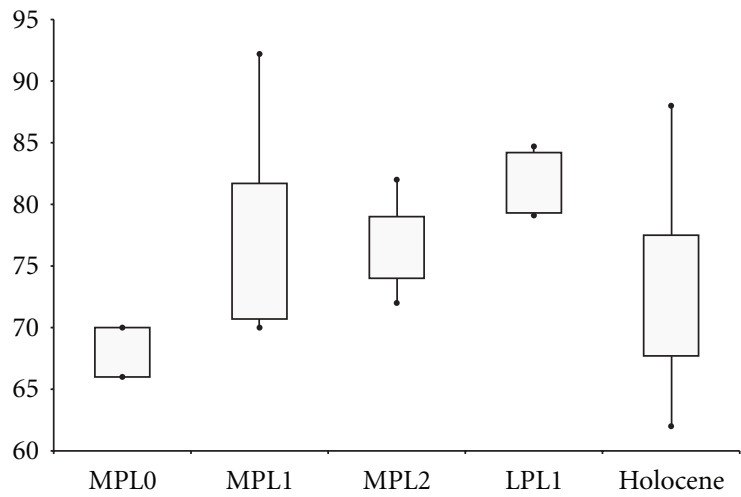

Figure 8: Box plot for the distal transverse diameter of the female metacarpus of Bos primigenius from Avetrana and from different sites of southern Europe (see Figure 6 caption).

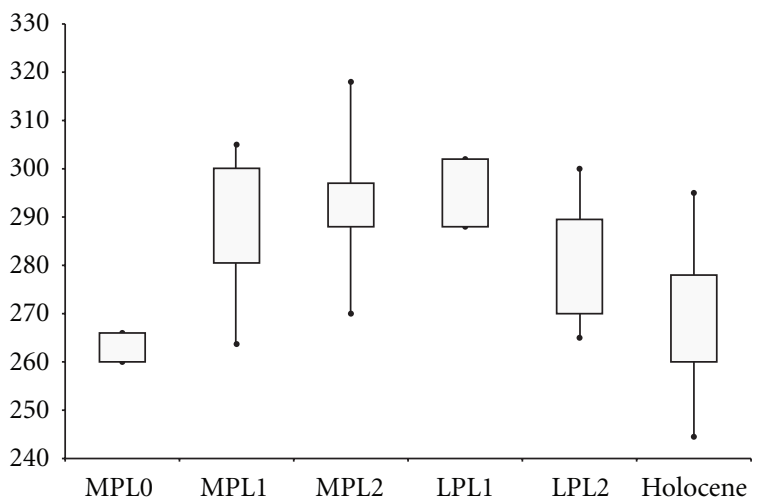

Figure 9: Box plot for the greatest length of the female metatarsus of Bos primigenius from Avetrana and from different sites of southern Europe (see Figure 6 caption).

the Middle Pleistocene (MPL0) is recognized even during the Holocene. This similarity is testified even by the Simpson diagram (Figure 11); in the latter the specimens from MPL0 and Holocene are well distinguished from the other.

During the late Middle Pleistocene (MPL1 and MPL2) and the early Late Pleistocene (represent by Avetrana), the metatarsus seems to have a more "columnar" shape. In these last, the diaphysis is more developed than the specimens from Middle Pleistocene and Holocene.

The general tendency of change in shape of the metatarsus is recognized even in the metacarpus, but with less evidence. The Simpson diagram shows a similar proportion of this bone for all the considered time spans but with relevant difference in size (Figure 12).

The variations of the ratio between the dimensional characters in the auroch seem to be strictly connected with the size variations; large-sized samples have more columnar and robust metapodial bones, while small-sized samples have a more slight metapodial one.

\section{Discussion}

Bos primigenius represent a common element of the Middle Pleistocene-Holocene fossil faunas of Europe and Asia; 


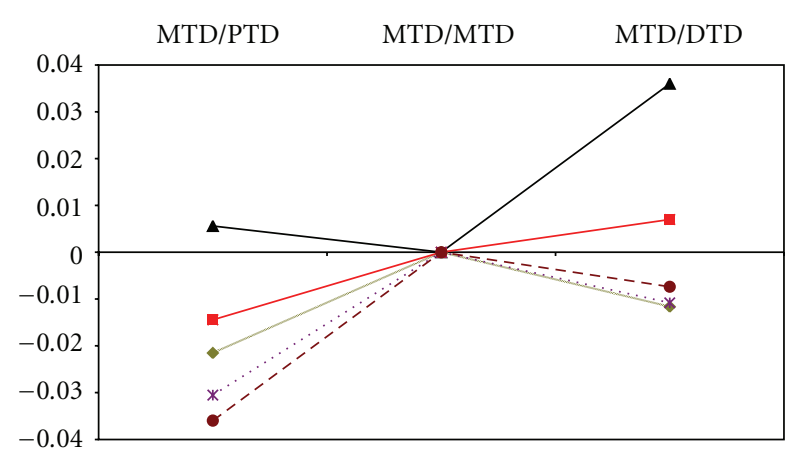

$$
\begin{aligned}
& \rightarrow \text { MPL0 … LPL2 } \\
& \rightarrow \text { MPL1 + MPL2 } \quad-\bullet \text { Holocene }
\end{aligned}
$$

Figure 10: Simpson diagram of ratio between the transverse diameter of diaphysis and epiphysis of the female metatarsus of Bos primigenius from Avetrana and different sites of southern Europe (see Table 1 and Figure 6 captions). The standard is Bison priscus from Cava Filo (data from Sala [37]).

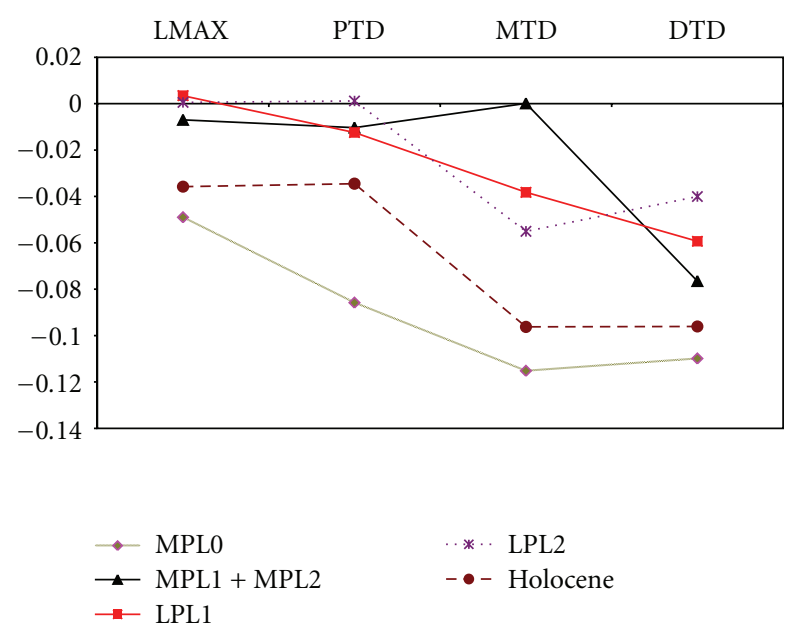

Figure 11: Simpson diagram of the metatarsus of female of Bos primigenius for the considered time spans (see Table 1 and Figure 6 captions). The standard is Bison priscus from Cava Filo (data from Sala [37]).

however, their origin is still debated. The oldest record of the genus Bos was reported in the Early-Middle Pleistocene transition at Asbole (Etiopia) [44] and in the Middle East at Gesher Benot Yaakov (Israel) [45]. In the 1998, Petronio and Sardella [46] ascribed a subintact skull to this genus and, on the bases of its morphology, proposed the new species Bos galerianus. This remain has been found in clay-layers of Cava di Breccia di Casal Selce (Rome, Italy), approximately related to the early Middle Pleistocene, about 0.8-0.7 Ma. However, the mentioned skull fragment was later referred to the Indian genus Hemibos by Martinez Navarro and Palombo [47, 48].

Recently, Martinez-Navarro et al. [49] connect the origin of the genus Bos with the Early Pleistocene African genus

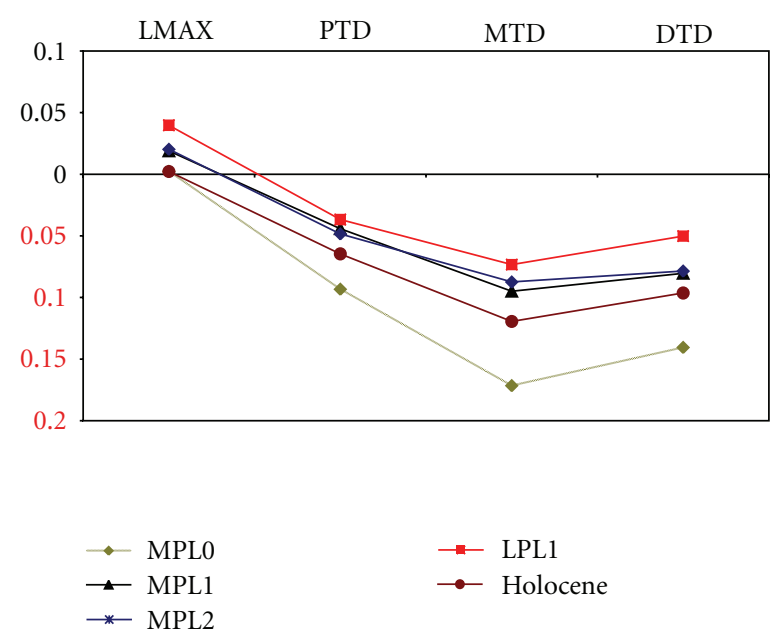

FIGURE 12: Simpson diagram of the matacarpus of female of auroch for the considered time spans (see Table 1 and Figure 6 captions). The standard is Bison priscus from Cava Filo (data from Sala [37]).

Pelorovis sensu strictu and propose that Pelorovis be included in the genus Bos. They supported this view based on anatomical and metrical data of the cranium and the teeth and considered different chronospecies: Bos turkanensis, older than 1.8 Ma; Bos oldowayensis, younger than $1.8 \mathrm{Ma}$; and $B$. primigenius for the Middle Pleistocene-Holocene forms of Eurasia and Africa. In 2010, Martinez-Navarro et al. [50] have described the new large-sized species Bos buiaensis from the late Early Pleistocene site of Buia (Eritrea) and have suggested that the remains from Asbole and Gesher Benot Yaakov can be referred to this species. According to the mentioned authors, Bos buiaensis dispersed in the Levantine Corridor and later into the North during the Early-Middle Pleistocene transition.

In Europe, the most ancient record of the genus Bos, referring to the species $B$. primigenius, is reported in the Middle Pleistocene Italian sites of Venosa (Matera) [24, 51] and GRA Km 2 (Rome) [26]. However, these records are represented by very fragmented and scarce materials, referable to female individuals. At the end of Middle Pleistocene, the species was present in several European sites and during the Late Pleistocene was very common in the Mediterranean Europe. At the beginning of the Holocene it was common even in the Continental Europe and it reached the greatest areal extension and the greatest frequency of remains: it was present in all Europe, Russia, North Africa, Asia Minor, northern India, and central China [15, 18, 20, $21,33,52-54]$. In historical age, $B$. primigenius reduced its areal diffusion and its abundance and survived in Poland up to $1627[5,55]$.

According to some authors $[2,18,32,56,57]$, the auroch is characterized by a relative decrease in size during the Late Pleistocene and in particular during the Holocene; largesized samples were reported in the late Middle Pleistocene sites as Lunel-Viel (France) and Via Aurelia (Rome, Italy). However, the marked sexual dimorphism of this species (see in particular $[18,33,38])$ has been not well considered 
by these authors. This fact has the consequence to hide the effective decrease or increase in size of the different populations during the time. Furthermore, in the different sites, the discovery of males and females in the same frequency is very rare (e.g., Avetrana).

In the present paper, the comparative analysis of the explained diagrams allows to recognize a trend in the dimensional variations of the female aurochs. In particular, we recognize an increment of the maximal length of the metacarpus and, partially, of the metatarsus from the Middle Pleistocene to the beginning of the Late Pleistocene and a decrease of the same measurement during the MIS3-4 and the ancient Holocene. The same trend of the maximal length is notice even in the distal transverse diameter of the metacarpus; this trend is less evident in the metatarsal bones because the few data about this measurement.

Also, we have notice a general variation in shape of the metapodial bones from the Middle Pleistocene to Holocene. In particular, the transverse diameter of the diaphysis tends to increase during the late Middle Pleistocene and decrease during the Late Pleistocene. An opposite trend is recognized in the distal transverse diameter. These changes are probably connected with the increase and decrease in size of the species.

Considering the probable area of origin of the auroch, characterized by a temperate-warm climate, we can justify the small size of the Middle Pleistocene form with the presence in southern Europe of a more cool climate. This hypothesis is in accordance with the larger size of Bos buiaensis related with a more favourable climate [50]. Furthermore, the first occurrence of the genus Bos in Europe, reported in the sites of Venosa (southern Italy) and GRA $\mathrm{Km} 2$ (Rome, Italy) [24, 26, 51], is related with the MIS 16 and 14 (about $650-550 \mathrm{ka}$, Isernia $\mathrm{FU}$ in the Italian biochronology) characterized by a cool temperate climate. The large-sized aurochs of the latest Middle Pleistocene and especially the early Late Pleistocene can be related with a warm temperate climate, as well as the decrease in size the climatic deteriorations of the last glacial event occurs.

Also, considering the presence/absence of other bovine, in particular Bison, and the increase of human presence, we have noticed some correlations with the variations in size of the aurochs. In particular, during the first occurrence of the Bos, in southern Europe the presence of Bison schoetensacki is very relevant. This last species disappeared during the late Middle Pleistocene, when the aurochs increase in size. Probably, the new ecological niches, previously occupied by bison, can favour the increased in size of the auroch because the more favourable climatic conditions. Furthermore, a relevant change in proportion of the metapodial bones is recorded. In fact, the specimens of the late Middle Pleistocene (MPL1 and MPL2) tend to have a general "columnar" shape respect to the Middle Pleistocene (MPL0) one.

In the Late Pleistocene, during the first Pleniglacial and the Interpleniglacial, the climatic deterioration and the extension of the steppe environment favour the increase of presence of Bison priscus in southern Europe (particularly in northern Italy, southern France, and Iberian peninsula), factors that can be competed to the decrease in size of
Bos primigenius. During the second Pleniglacial stage and the Holocene, the affirmation of human presence in southern Europe can be the prevailing factors in the progressive rarefaction and the decrease in size of aurochs. During this time span, auroch had dimensions and proportions similar to that of the Middle Pleistocene. However, it should be considered that, with rare exceptions, the majority of the auroch remains relating to the "cold" Late Pleistocene and the Holocene come from sites where the main or exclusive agent of accumulation of the bone remains is man. The small size of these specimens could therefore be attributable not only to the climatic fluctuations and the anthropogenic pressure (first the hunting, then the competition with domestic cattle and the habitat reduction), but also to a selection made by human beings according to their dietary and/or hunting preferences.

\section{Concluding Remarks}

We report here the preliminary description of an abundant population of Bos primigenius discovered in the early Late Pleistocene site of Avetrana. The biometrical analysis of the metapodial bones of the auroch from Avetrana and the comparisons with the other populations of the same species from different sites of southern Europe allow the recognization of an evolutive trend. This trend is characterized by five stage, connected to climatic fluctuations and species competitions (versus Bison and Homo).

(1) The first stage is characterized by a Middle Pleistocene small-sized population with a "clepsydra" shape in the metapodial bones. This size is probably connected with the cool temperate climate of the MIS $16-14$.

(2) The second stage is characterized by an increase in size and by the change in shape of the metapodial bones. This is probably related with warm temperate climate and with the decrease of the bison populations in southern Europe during the late Middle Pleistocene.

(3) The third stage is represented by very large-sized specimens, present during the early Late Pleistocene and probably connected with the optimum climate stage.

(4) The fourth stage is characterized by a decrease in size, probably connected with the climatic deterioration of the late Late Pleistocene, the diffusion of the Bison priscus in southern Europe, and the affirmation of human presence.

(5) The fifth stage is represented by a small-sized populations, similar to that of Middle Pleistocene. This is probably related with the definitive affirmation of the Homo in the considered area and with the consequences of the last glacial maximum.

The results of this preliminary analysis constitute an additional and important tool in the biochronological correlations among the Pleistocene sites of southern Europe. 


\section{References}

[1] R. Sardella, C. Bedetti, L. Bellucci et al., "The late pleistocene vertebrate fauna from avetrana (Taranto, Apulia, southern Italy): preliminary report," Geology of the Alps, vol. 2, pp. 2529, 2005.

[2] C. Petronio, F. Bellardini, M. Arzarello et al., "The deposit of the Late Pleistocene from Avetrana (Taranto, southern Italy): biochronology and palaeoecology. Il," Quaternario, vol. 21, no. 2, pp. 409-422, 2002.

[3] P. L. Gibbard, M. J. Head, and M. J. C. Walker, "Formal ratification of the Quaternary System/Period and the Pleistocene Series/Epoch with a base at $2.58 \mathrm{Ma}$," Journal of Quaternary Science, vol. 25, no. 2, pp. 96-102, 2010.

[4] N. Ciaranfi, M. Maggiore, P. Pieri, L. Rapisardi, G. Ricchetti, and N. Walsh, "Considerazioni sulla neotettonica della Fossa Bradanica," in Nuovi Contributi Alla Realizzazione Della Carta Neotettonica d'Italia, vol. 251, pp. 73-96, C.N.R. Progetto Finalizzato Geodinamica, Napoli, Italy, 1979.

[5] C. Petronio, E. Di Canzio, and L. Salari, "The Late Pleistocene and Holocene mammals in Italy: new biochronological and paleoenvironmental data," Palaeontographica, Abteilung A, vol. 279, no. 4-s6, pp. 147-157, 2007.

[6] E. Gliozzi, L. Abbazzi, P. G. Ambrosetti et al., "Biochronology of selected mammals, molluscs and ostracods from the middle pliocene to the late pleistocene in Italy. The state of the art," Rivista Italiana di Paleontologia e Stratigrafia, vol. 103, no. 3, pp. 369-388, 1997.

[7] C. Petronio, L. Bellucci, E. Martinetto, L. Pandolfi, and L. Salari, "Biochronology and Palaeoenvironmental Changes from the Middle Pliocene to the Late Pleistocene in central Italy," Geodiversitas. In press.

[8] T. Kotsakis, L. Abbazzi, C. Angelone et al., "Plio-Pleistocene biogeography of Italian mainland micromammals," Deinsea, vol. 10, pp. 313-342, 2003.

[9] L. Salari and R. Sardella, "The Pleistocene porcupine Hystrix vinogradovi Argyropulo, 1941 in Italy," Bollettino della Societa Paleontologica Italiana, vol. 48, no. 2, pp. 123-127, 2009.

[10] G. Bartolomei, "Considerazioni ecologiche sulle faune pleistoceniche dell'Europa contenenti scimmie ed istrici," in Scritti sul Quaternario in onore di Angelo Pasa, pp. 39-52, Verona, Italy, 1969.

[11] C. Petronio and R. Sardella, "Remarks on the stratigraphy and biochronology of the late pleistocene deposit of Ingarano (Apulia, Southern Italy)," Rivista Italiana di Paleontologia e Stratigrafia, vol. 104, no. 2, pp. 287-294, 1998.

[12] G. Di Stefano and C. Petronio, "Origin and evolution of the European fallow deer (Dama, Pleistocene)," Neues Jahrbuch für Geologie und Paläontologie, vol. 203, no. 1, pp. 57-75, 1997.

[13] G. Di Stefano and C. Petronio, "A new Cervus elaphus of Middle Pleistocene age. Neues Jahrbuch für Geologie und Paläontologie," Abhandlungen, vol. 190, no. 1, pp. 1-18, 1997.

[14] A. von den Driesch, A Guide to the Measurement of Animal Bones from Archaeological Sites, vol. 1, Harvard University, Cambridge, Mass, USA, 1976.

[15] H. von Requate, "Zur naturgeschichte des ures, Bos primigenius, nach Schädel-und skelettfunden in schleswig-holstein," Zeitschrift für Tierzüchtung und Züchtungsbiologie, vol. 70, pp. 297-338, 1957.

[16] C. Arambourg, "Les gros mammifères des couches tayaciennes," in La Grotte de Fontèchevade, vol. 29, part 3, pp. 185229, Archives Institut de Palèontologie Humaine, Mèmoires, 1958.
[17] H. R. Stampfli, "Wisent bison bonasus (Linné, 1758), Ur, Bos primigenius Bojanus, 1827, und hausrind, Bos taurus Linné," in Seeberg Burgäschisee-Süd. Die Tierreste, J. Boessneck, I. P. Jequier, and H. R. Stampfli, Eds., vol. 2, part 3, pp. 117-196, Acta Bernensia, 1758.

[18] M. Degerbøl and B. Fredskild, "The urus (Bos primigenius Bojanus) and neolitic domesticated cattle (Bos taurus domesticus Linnè) in Denmark, with a revision of Bos-remains from the kitchen middens. Zoological and palynological investigations," Biologiske Skrifter, vol. 17, no. 1, pp. 1-234, 1970.

[19] C. C. Flerow and V. J. Reshetov, "Fossil bison and Bos from stranska skala. Anthropos (Praha)," Studia Musei Moraviae, vol. 20, no. 12, pp. 177-179, 1972.

[20] S. P. Gerber, La faune des grandes mamimiferees du Würm ancien dans le sud de la France, Ph.D. thesis, Université de Provence, 1972.

[21] J. Altuna, "Hallazgo de un uro (Bos primigenius boj) en la sierra de Gibijo (Alava). Estudio de su esqueleto y de la fauna asociada al mismo," Munibe, vol. 26, pp. 27-51, 1974.

[22] A. Riedel, "La fauna del villaggio preistorico di barche di solferino," Atti Museo Civico Storia Naturale di Trieste, vol. 29, pp. 215-318, 1976.

[23] L. Caloi and M. R. Palombo, "Anfibi, rettili e mammiferi di Torre del Pagliaccetto (Torre in Pietra, Roma)," Quaternaria, vol. 20, pp. 315-428, 1978.

[24] L. Caloi and M. R. Palombo, "La fauna quaternaria di Venosa: Bovidi,” Bollettino Servizio Geologico d'Italia, vol. 100, pp. 101140, 1979.

[25] L. Caloi and M. R. Palombo, "Resti di mammiferi del Pleistocene medio di Malagrotta (Roma)," Bollettino Servizio Geologico d'Italia, vol. 100, pp. 141-188, 1979.

[26] L. Caloi and M. R. Palombo, "Resti di mammiferi in livelli del Pleistocene medio inferiore affioranti al $\mathrm{Km} 2$ del G.R.A. (Roma)," Bollettino Servizio Geologico d'Italia, vol. 104, pp. 141-156, 1986.

[27] L. Caloi, M. R. Palombo, and C. Petronio, "La fauna quaternaria di Sedia del Diavolo (Roma)," Quaternaria, vol. 22, pp. 177-209, 1980.

[28] L. Caloi, M. C. Cuggiani, A. Palmarelli, and M. R. Palombo, "La fauna a vertebrati del Pleistocene medio e superiore di Vitinia (Roma)," Bollettino Servizio Geologico Italiano, vol. 102, pp. 41-75, 1983.

[29] J.-C. Descombes, La Premiere Faune Rissienne de la Basse Vallée de la Seine. Implications Biostratigraphiques et Paleoecologiques, These 3eme cycle, Université de Poitiers, 1980.

[30] D. Jánossy and I. Vörös, "Pleistozäner Skelettfund der Ures (Bos pimigenius Bojanus) von Nagybajom (Ungarn)," Fragmenta Mineralogica et Palaeontologica, vol. 10, pp. 79-96, 1980.

[31] M. Campy, L. Chaix, U. Eicher, J. Mouthon, H. Richard, and J. P. Urlacher, "L'aurochs (Bos primigenius boj.) d'Etival (Jura, France) et la séquence tardi et postglaciaire sur les plateaux jurassiens," Revue de Paléobiologie, vol. 2, no. 1, pp. 61-85, 1983.

[32] J. P. Brugal, Applications des analyses multidimensionnelles à l'étude du squelette des membres des grands bovidés Pléistocènes (grottes de Lunel-Viel. Hérault) : perspectives évolutives, doctorate thesis, Université Aix-Marseille II, 1983.

[33] J. P. Brugal, "Le Bos primigenius boj., 1827 du Pléistocène moyen des grottes de Lunel-Viel (Hérault)," Bulletin Musée d'Anthropologie Préhistorique de Monaco, vol. 28, pp. 7-62, 1985. 
[34] I. Vörös, "An aurochs (Bos primigenius boj.) skeleton from the Mesolithic peatbogs at Kecel- rózsaberek," Folia Archaeologica, vol. 38, pp. 65-88, 1987.

[35] A. Tuffreau, P. Antoine, P. Chase et al., "Le gisement acheuléen de Cagny-l'Epinette (Somme)," Bulletin de la Société Préhistorique Française, vol. 92, pp. 169-191, 1995.

[36] C. Petronio and R. Sardella, "Biochronology of the Pleistocene mammal fauna from Ponte Galeria (Rome) and remarks on the Middle Galerian faunas," Rivista Italiana di Paleontologia e Stratigrafia, vol. 105, no. 1, pp. 155-164, 1999.

[37] B. Sala, "Bison schoetensacki Freud. from Isernia la Pineta (early Mid-Pleistocene-Italy) and revision of the european species of bison," Palaeontographia Italica, vol. 74, pp. 113$170,1986$.

[38] C. Grigson, "The craniology and relationships of four species of Bos. 4. The Relationship between Bos primigenius Boj. and B. taurus L. and its implications for the Phylogeny of the Domestic Breeds," Journal of Archaeological Science, vol. 5, no. 2, pp. 123-152, 1978.

[39] M. Howard, "The metrical determination in the metapodials and skulls of cattle. Man and cattle," Royal Anthropological Institute, Occasional Paper, vol. 18, pp. 91-100, 1963.

[40] I. E. Silver, "The ageing of domestic animals," in Science in Archaeology, D. R. Brothwell and E. Higgs, Eds., pp. 283-302, Thames and Hudson, London, UK, 1969.

[41] R. Barone, Anatomia Comparata dei Mammiferi Domestici, I-Osteologia, III-Splancnologia, Edagricole, Bologna, Italy, 1974, Edited by R. di Bortolami.

[42] J. Matolcsi, "Historesche Erforschung der Köpergrösse des Rindes auf Grund von ungarischen Knochen material," Zeitschrift für Tierzüchtung und Züchtungsbiologie, vol. 87, no. 2, pp. 89-137, 1969.

[43] P. Bologna and C. Petronio, "The first occurrence of Bison priscus Bojanus in the Melpignano area (Lecce, southern Italy," Bollettino-Societa Paleontologica Italiana, vol. 33, no. 2, pp. 275-278, 1994.

[44] D. Geraads, Z. Alemseged, D. Reed, J. Wynn, and D. C. Roman, "The Pleistocene fauna (other than Primates) from Asbole, lower Awash Valley, Ethiopia, and its environmental and biochronological implications," Geobios, vol. 37, no. 6, pp. 697-718, 2004.

[45] B. Martínez-Navarro and R. Rabinovich, "The fossil bovidae (Artiodactyla, Mammalia) from Gesher Benot Ya'aqov, Israel: out of Africa during the Early-Middle Pleistocene transition," Journal of Human Evolution, 2010.

[46] C. Petronio and R. Sardella, "Bos galerianus n. sp. (Bovidae, Mammalia) from the Ponte Galeria Formation (Rome, Italy)," Neues Jahrbuch fur Geologie und Palaontologie-Monatshefte, no. 5, pp. 269-284, 1998.

[47] B. Martínez-Navarro and M. R. Palombo, "Occurrence of the Indian genus Hemibos (Bovini, Bovidae, Mammalia) at the Early-Middle Pleistocene transition in Italy," Quaternary Research, vol. 61, no. 3, pp. 314-317, 2004.

[48] B. Martinez-Navarro and M. R. Palombo, "The horn-core of Hemibos galerianus from Ponte Milvio, Rome (Italy)," Rivista Italiana di Paleontologia e Stratigrafia, vol. 113, no. 3, pp. 531534, 2007.

[49] B. Martínez-Navarro, J. Antonio Pérez-Claros, M. R. Palombo, L. Rook, and P. Palmqvist, "The olduvai buffalo Pelorovis and the origin of Bos," Quaternary Research, vol. 68, no. 2, pp. 220 226, 2007.
[50] B. Martínez-Navarro, L. Rook, M. Papini, and Y. Libsekal, "A new species of bull from the Early Pleistocene paleoanthropological site of Buia (Eritrea): parallelism on the dispersal of the genus Bos and the Acheulian culture," Quaternary International, vol. 212, no. 2, pp. 169-175, 2010.

[51] P. F. Cassoli, G. Di Stefano, and A. Tagliacozzo, "I vertebrati dei livelli superiori (A e Alfa) della serie stratigrafica di Notarchirico," in Notarchirico. Un Sito del Pleistocene MedioIniziale nel Bacino di Venosa (Basilicata), M. Piperno, Ed., vol. 1, pp. 361-438, Osanna, Venosa, 1999.

[52] A. W. Gentry, "Bovidae," in Evolution of African Mammals, V. J. Maglio and H. P. S. Cocke, Eds., pp. 540-572, Howard University Press, Cambridge, UK, 1978.

[53] J. Murray, The First Europian Agricolture, A Study of the Osteological and Botanical Evidence Until 2000 BC, Edinburgh University Press, Edinburgh, UK, 1970.

[54] C. Guintard and J. Rewerski, "Disparition de l'Aurochs en Pologne au XVIIe siècle, et projet de rèintroduction de l'Aurochs-reconstituè en Mazury, animaux perdus, animaux retrouvé: réapparition ou en Europe occidentale d'espèces reintroduction disparu de leur milieu d'origine. Journée d'étude, 21 mars," in Colloques D'Histoire des Connaissances Zoologiques, L. Bodson, Ed., vol. 10, pp. 57-104, Università de Liège, Liège, Belgium, 1998.

[55] K. Heymanowski, "The last mainstay of aurochs and the organization of their protection in the light of contemporary documents," Sylwan, vol. 116, no. 9, pp. 9-28, 1972.

[56] C. Grigson, "The uses and limitations of differences in absolute size in the distinction between the bones of aurochs (Bos primigenius) and domestic cattle (Bos taurus)," in The Domestication and Exploitation of Plants and Animals, P. J. Ucko and G. W. Dimbleby, Eds., pp. 277-294, Duckworth, London, UK, 1969.

[57] E. Cerilli and C. Petronio, "Biometrical variations of Bos primigenius Bojanus," in Proceedings of the International Symposium “Ongules/Ungulates 91”, pp. 37-42, Toulouse, France, 1992. 

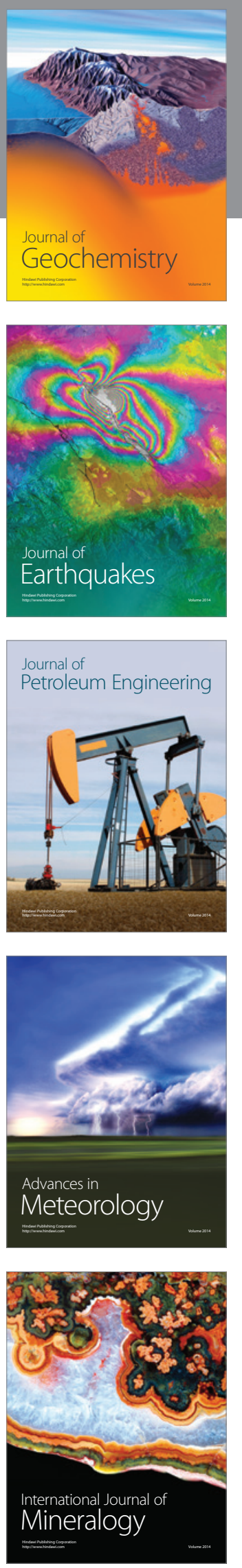
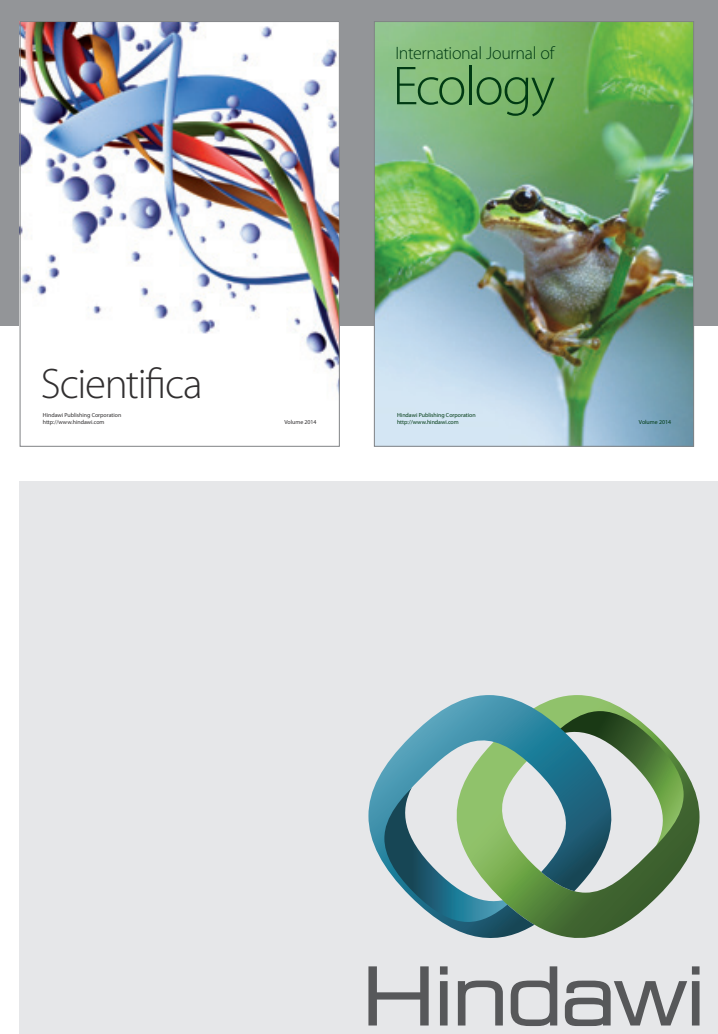

Submit your manuscripts at http://www.hindawi.com
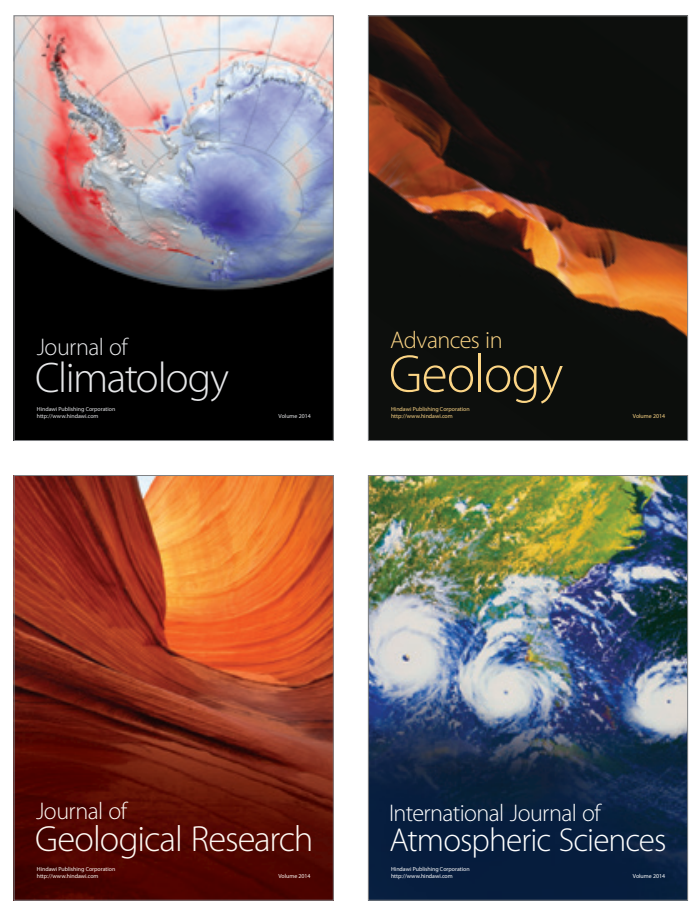
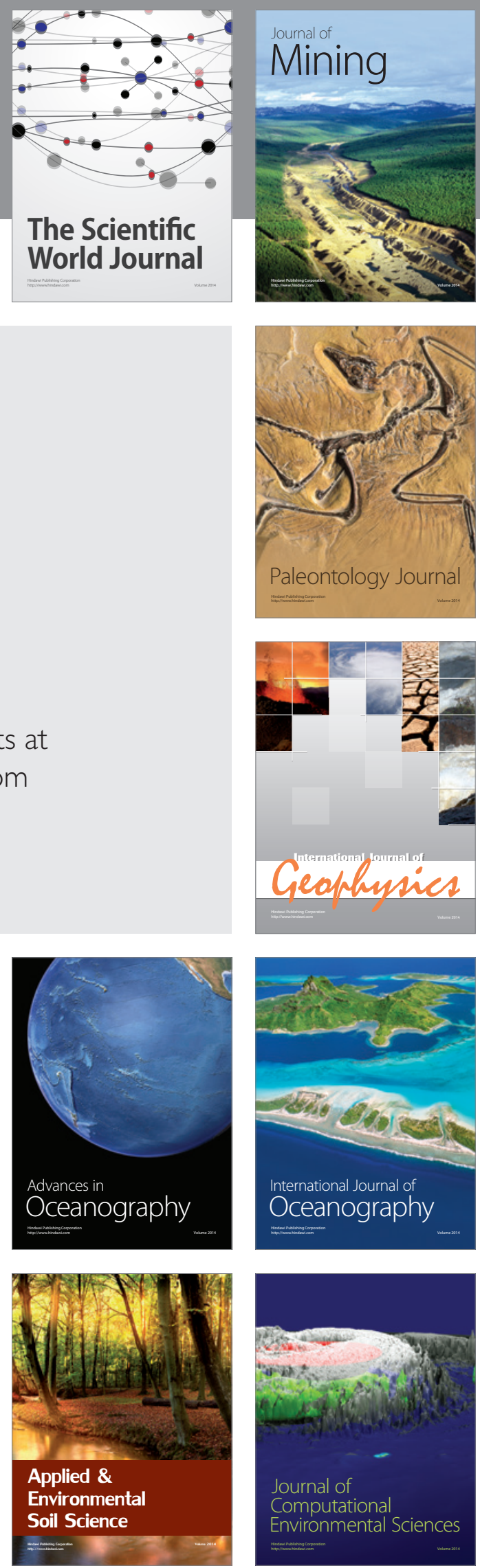